\title{
Do overweight and obese individuals demonstrate impaired thermoregulatory adaptation to six weeks of studio cycling training: A pilot study
}

\author{
Steve H Faulkner ${ }^{*}$, Kieran Menon, Thomas M Hood, Jamie K Pugh, Myra A Nimmo \\ From 15th International Conference on Environmental Ergonomics (ICEE XV) \\ Portsmouth, UK. 28 June - 3 July 2015
}

\begin{abstract}
Introduction
High intensity interval training (HIIT) is effective at improving health markers in groups at risk of cardiovascular and metabolic disease. Studio cycling may offer a platform for HIIT in the community, however little is know about how increased adiposity influences thermal control during HIIT and the effect this may have on overweight patients who are new to exercise. The purpose of this pilot study was to investigate the thermal adaptation in response to studio based group HIIT in sedentary overweight adults.
\end{abstract}

\section{Methods}

Eight, overweight, physically inactive $(86.1(10.6) \mathrm{kg}$; $\dot{\mathrm{V}} \mathrm{O}_{2 \max }$ 27.1(4.7) mL.kg.min ${ }^{-1}$; BSA $1.97(0.16) \mathrm{m}^{2}$; 31.8 (2.4) \%body fat; $<1.5$ hr.wk ${ }^{-1}$ of physical activity) otherwise healthy volunteers completed six 30 minute familiarisation sessions followed by 6 weeks of supervised studio cycling 3 times per week. All sessions were completed in a ventilated but non-temperature controlled group fitness studio. Thermal measures were completed in weeks 1,3 and 6 for all participants. Participants were weighed in minimal clothing before and after exercise, which was corrected for fluid intake to determine sweat loss. During the session, wireless thermistors were attached to the skin for the calculation of mean skin temperature $\left(\bar{T}_{\text {sk }}\right)$ and heart rate was recorded for intensity assessment. All data presented as mean (SD).

\section{Results}

Mean ambient temperature across all weeks was $19.6 \pm$ $1.7^{\circ} \mathrm{C}$. The mean and peak exercise intensity equated to

\footnotetext{
* Correspondence: S.Faulkner2@lboro.ac.uk

School of Sport, Exercise and Health Sciences, Loughborough University, Loughborough, UK
}

\section{Discussion}

The present data suggest that there may be some impairment of thermoregulatory adaptation in response to regular indoor cycle training in overweight and obese individuals. The decline in $\overline{\mathrm{T}}_{\mathrm{sk}}$ in week 3 compared to week 1 prior to an elevation in $\overline{\mathrm{T}}_{\text {sk }}$ in week 6 suggests that the thermal adaptation response evident in healthy lean individuals may be hindered in overweight. It is likely that this response is in someway due to elevated adipose tissue in these individuals. Increased adiposity will impair conductive heat exchange from core to skin 
during exercise and is further compounded by the low specific heat of fat compared to skeletal muscle. This will therefore limit changes in $\bar{T}_{\mathrm{sk}}$ and heat loss during initial training bouts until body fat is reduced, exposing these individuals to a potentially higher risk of heat illness.

\section{Conclusion}

Care should be taken when overweight or obese individuals begin exercise training, as it is possible that they may experience greater thermoregulatory strain in the initial phases of training before heat acclimation begins to occur. Further work should consider the effect that increasing exercise prescription to overweight and obese populations has on the risk of heat related complications.

Published: 14 September 2015

doi:10.1186/2046-7648-4-S1-A115

Cite this article as: Faulkner et al:: Do overweight and obese individuals

demonstrate impaired thermoregulatory adaptation to six weeks of studio cycling training: A pilot study. Extreme Physiology \& Medicine 2015 4(Suppl 1): A115.
Submit your next manuscript to BioMed Central and take full advantage of:

- Convenient online submission

- Thorough peer review

- No space constraints or color figure charges

- Immediate publication on acceptance

- Inclusion in PubMed, CAS, Scopus and Google Scholar

- Research which is freely available for redistribution

Submit your manuscript at www.biomedcentral.com/submit 